\title{
Refinement of fertilizer recommendation based on Soil Test Crop Response technology for rice under System of Rice Intensification
}

\author{
M. Vijayakumar ${ }^{* 1}$, R. Santhi ${ }^{2}$ and S. Mohamed Jalaluddin ${ }^{1}$ \\ ${ }^{1}$ Regional Research Station, Tamil Nadu Agricultural University, Paiyur, Krishnagiri-635112 (Tamil Nadu), INDIA \\ ${ }^{2}$ Department of Soil Science and Agricultural Chemistry, Tamil Nadu Agricultural University, Coimbatore- 641003 , \\ (Tamil Nadu) INDIA \\ *Corresponding author. E-mail: vijayagri1985@gmail.com
}

Received: June 23, 2016; Revised received: January 4, 2017; Accepted: April 26, 2017

\begin{abstract}
A study on Soil Test Crop Response based Integrated Plant Nutrition System (STCR - IPNS) were conducted adopting an Inductive cum Targeted yield model in non-calcareous sandy loam soils of Lithic Haplusteptat Regional Research Station, Tamil Nadu Agricultural University, Paiyur, Tamil Nadu during Kharif 2013 in orderto develop fertilizer prescriptions equation (FPEs) through IPNS for the desired yield targets of rice under SRI technique. A ready reckoner of fertilizer doses at varying soil test value, for attaining 6 to $9 \mathrm{t} \mathrm{ha}^{-1}$ target grain yield of rice has been worked out. Using these equations a validation trial was conducted on Kharif 2014 at this station. The grain yield of rice ranged from $2.54 \mathrm{t} \mathrm{ha}^{-1}$ in absolute control to $8.65 \mathrm{t} \mathrm{ha}^{-1}$ in STCR-IPNS-9 $\mathrm{t}$ ha $\mathrm{I}^{-1}$. The STCR-IPNS @ $8 \mathrm{t} \mathrm{ha}^{-1}$ was effective and economical as compare with any other treatments. The deviation recorded in the achievement of targets aimed was within the range of \pm 10 per cent $(90-110 \%)$ proving the validity of the FPEs. The STCR treatments recorded relatively higher response ratio (RR) and benefit-cost ratio (BCR) over blanket and farmer's practice and STCR-IPNS treatments recorded relatively higher RR and BCR over STCR-NPK alone treatments. Post-harvest soil tests for NPK revealed that there was maintenance of soil fertility. The STCR-IPNS @ $8 \mathrm{t}$ $\mathrm{ha}^{-1}$ was effective and economical as compare with any other treatments. Thus, the Inductive cum Targeted yield model used to develop fertilizer prescription equations provides a strong basis for soil fertility maintenance consistent with high productivity and efficient nutrient management for sustainable and enduring Agriculture.
\end{abstract}

Keywords: Fertilizer prescription equations, Lithic Haplustept, SRI technique, STCR - IPNS

\section{INTRODUCTION}

Rice is the major crop of India and occupies largest cropped area of 42.4 million hectares with an annual production of 100 million tones and the productivity is $2462 \mathrm{~kg} \mathrm{ha}^{-1}$ (DAC, 2013). It's an important major crop in Tamil Nadu and is accounted for 29.3 per cent $(1.73$ mha) of the total cropped area with total production of 7.1 million tones (Season and Crop Report, 2015). Over-exploitation of soils over many decades has resulted in the exhaustion of the agricultural production systems and steadily declining productivity has been noticed in long term experiments in Asia (Bhandari et al., 2002; Ladha et al., 2003; Manna et al., 2005). The decision on fertilizer use requires knowledge of the expected crop yield response to nutrient application, which is a function of crop nutrient needs, supply of nutrients from indigenous sources, and the short and long-term fate of the applied fertilizer nutrients (Dobermann et al., 2003).

The Soil test based fertilizer recommendation harmonizes the much debated approaches namely, "Fertilizing the soil" versus "Fertilizing the crop" ensuring for real balance (not apparent balance) between the applied fertilizer nutrients among themselves and with the soil available nutrients. Based on this concept, soil test crop response studies have been undertaken in different parts of India in various crops like wheat, rice, pearl millet (Subba Rao and Srivastava, 2000). Truog (1960) illustrated the possibility of "Prescription method" of fertilizer use for obtaining high yields of corn using empirical values of nutrient availability from soil and fertilizer. However, Ramamoorthy and his associates established during 1965-67 the theoretical basis and field experimental proof and validation for the fact that Liebiges Law of Minimum of Plant nutrition (Liebig, 1855) operates equally well for N, P and $\mathrm{K}$ for the high yielding varieties of wheat, rice and pearl millet.

The system of rice intensification (SRI) is said to be an innovation of civil society, impressed by its input saving techniques and success under varying environments, our country has also started its formal research to strengthen the scientific principles behind SRI (Prasad, 2006). Ravindra Babu et al. (2006) stated that SRI method is described by the cliché, "more crop for drop" as it requires only about half as much water normally applied in irrigated rice production system. It is 
a combination of plant, soil, water and nutrient management practices that are employed in SRI which enhances (1) robust root growth (2) corresponding increase in tillering (3) greater grain filling in higher grain yield. The rice yield could be tripled by adopting SRI method compared to traditional method of cultivation mainly due to planting of seedling before third phyllocron leads to higher productive tillers and yield (Andrainaivo and Jolei, 2002).

Stockdale et al. (2001) stated that the soil fertility is the combination of physical, chemical and biological properties which provide a medium and nutrients for plant growth also foundation on which all inputs based production system can be built for higher crop yield. Khosa et al. (2012) also reported the superiority of the target yield concept over other practices for different crops as it gave higher yields and optimal economic returns. The specific yield equation based on soil health besides ensuring sustainable crop production also steers the farmers towards economic use of costly fertilizer inputs depending on their financial status and prevailing market price of the crop under consideration (Bera et al., 2006). The study also intended to find the relationship between the nutrients supplied by the soil and added by organic and inorganic sources, their uptake and to develop a guideline for judicious application of fertilizer for desired yield target of rice by using STCR model.

\section{MATERIALS AND METHODS}

Studies on soil test crop response based balanced fertilization for rice (Paiyur-1), fertilizer prescription equations under IPNS were developed for Inceptisols (Lithic Haplustept) of Krishnagiri district during 201315 following the Inductive cum Targeted yield model of Ramamoorthy et al. (1967).The field experiments were conducted at Regional Research Station, Tamil Nadu Agricultural University, Paiyur at Krishnagiri of Tamil Nadu, on Inceptisol (Lithic Haplustept). The station is located in the North-westagro climatic zone of Tamil Nadu at $12.21^{\circ} \mathrm{N}$ Latitude and $78.18^{\circ} \mathrm{E}$ Longitude at an altitude of $490 \mathrm{~m}$ above MSL. The gradient and test crop experiments comprised of nine treatments viz., $\mathrm{T}_{1}$-Blanket recommendation $(150: 50: 50 \mathrm{~kg}$ $\left.\mathrm{N}: \mathrm{P}_{2} \mathrm{O}_{5}: \mathrm{K}_{2} \mathrm{O} \mathrm{ha}^{-1}\right) ; \mathrm{T}_{2}$-STCR-NPK alone $-7 \mathrm{tha}^{-1} ; \mathrm{T}_{3^{-}}$ STCR-NPK-8 $\mathrm{t} \mathrm{ha}^{-1}$; T 4 -STCR-NPK-9 $\mathrm{t} \mathrm{ha}^{-1}$; $\mathrm{T}_{5}$-STCR -IPNS-7 t ha ${ }^{-1}$; $\mathrm{T}_{6}$-STCR-IPNS-8 $\mathrm{t} \mathrm{ha} \mathrm{ha}^{-1} ; \mathrm{T}_{7}$-STCRIPNS-9 t ha ${ }^{-1} ; \mathrm{T}_{8}$-FYM @ $12.5 \mathrm{t} \mathrm{ha}^{-1}$ alone; $\mathrm{T}_{9}$-absolute control were conducted during kharif 2013 and the validation (above treatment structures same except FYM@12.5 t ha ${ }^{-1}\left(\mathrm{~T}_{8}\right)$ instead farmers practice was included) of experimental trial conducted during kharif 2014. The field experiment was laid out in a Randomized Block Design (RBD) with three replications. The soil of the experimental field belongs to Vannapatti series (red non-calcareous) taxonomically referred to as Lithic Haplustept exhibiting sandy loam texture.
Soil samples were collected, dried and passed through $2 \mathrm{~mm}$ sieve and analyzed for physicochemical properties as described by Jackson (1973). Available nitrogen, by the alkaline per manganate method (Subbiah and Asija, 1956); available phosphorus, by Olsen et al. (1954) and available potassium, by the ammonium acetate method (Hanway and Heidal, 1952) as described by Jackson (1973). Pre sowing soil samples were analyzed according to the standardprocedures.Soil resource inventory of the study areais moderately alkaline reaction ( $\mathrm{pH} 8.1)$ and non-saline conditions (EC $0.10 \mathrm{dS} \mathrm{m}^{-1}$ ). The initial soil fertility status showed low available $\mathrm{N}\left(204 \mathrm{~kg} \mathrm{ha}^{-1}\right)$, medium available $\mathrm{P}\left(12 \mathrm{~kg} \mathrm{ha}^{-1}\right)$, and low available $\mathrm{K}\left(96 \mathrm{~kg} \mathrm{ha}^{-1}\right)$. The fertilizer prescription equations for desired yield targets of rice under SRI during sambawas developed under NPK alone and IPNS using basic parameters and are presented below.

NPK alone, IPNS (NPK + FYM @ $12.5 \mathrm{t} \mathrm{ha}^{-1}$ ) FN $=3.49 \mathrm{~T}-0.36 \mathrm{SN}, \mathrm{FN}=3.49 \mathrm{~T}-0.36 \mathrm{SN}-0.74 \mathrm{ON}$ $\mathrm{FP}_{2} \mathrm{O}_{5}=1.66 \mathrm{~T}-2.76 \mathrm{SP}, \mathrm{FP}_{2} \mathrm{O}_{5}=1.66 \mathrm{~T}-2.76 \mathrm{SP}-0.69 \mathrm{OP}$ $\mathrm{FK}_{2} \mathrm{O}=2.19 \mathrm{~T}-0.66 \mathrm{SK}_{2} \mathrm{FK}_{2} \mathrm{O}=2.19 \mathrm{~T}-0.66 \mathrm{SK}-0.52 \mathrm{OK}$ Where, FN, $\mathrm{FP}_{2} \mathrm{O}_{5}$ and $\mathrm{FK}_{2} \mathrm{O}$ are fertilizer $\mathrm{N}, \mathrm{P}_{2} \mathrm{O}_{5}$ and $\mathrm{K}_{2} \mathrm{O}$ in $\mathrm{kg} \mathrm{ha}^{-1}$ respectively; $\mathrm{T}$ is the yield target in $\mathrm{q}$ ha ${ }^{-1}$; SN, SP and SK respectively are alkaline $\mathrm{KMnO}_{4}-\mathrm{N}$, Olsen-P and $\mathrm{NH}_{4} \mathrm{OAc}-\mathrm{K}$ in $\mathrm{kg} \mathrm{ha}^{-1}$; ON, OP and $\mathrm{OK}$ are the quantities of $\mathrm{N}, \mathrm{P}$ and $\mathrm{K}$ supplied through FYM $\mathrm{kg} \mathrm{ha}^{-1}$.

\section{RESULTS AND DISCUSSION}

Yield targeting of rice based on soil test: From the field experiment the basic data on nutrient requirement for producing one quintal of grain yield of rice, percent contribution of nutrients from soil (\% CS) and fertilizer $(\% \mathrm{CF})$ were evaluated. These basic parameters were used for developing the fertilizer prescription equations under NPK alone and IPNS. The nutrient requirement of $\mathrm{N}, \mathrm{P}_{2} \mathrm{O}_{5}$ and $\mathrm{K}_{2} \mathrm{O}$ were $1.57,0.71$ and $1.98 \mathrm{~kg} \mathrm{q}^{-1}$ of grain yield, respectively. The percent contribution of nutrients from soil, fertilizers and organic manure were found to be $16.18,44.97$ and 33.29 for $\mathrm{N}, 51.64,42.89$ and 12.88 for $\mathrm{P}_{2} \mathrm{O}_{5}$ and 49.48, 90.46 and 39.14 for $\mathrm{K}_{2} \mathrm{O}$, respectively. It was noted that contribution of potassium from fertilizer for rice was higher in comparison to soil. This high value of potassium could be to interaction effect of higher doses of $\mathrm{N}$, P coupled with priming effect of starter $\mathrm{K}$ doses in the treated plots, whichmight have caused the release of soil potassium form, resulting in the higher uptake from the native soil sources by the crop (Ray et al. 2000). Similar, type of higher efficiency of potassic fertilizer was also reported for rice by Ahmed et al. (2002) in alluvial soils and for finger millet by Kadu and Bulbule (2007).

The results of the experimental trial revealed that the targeted yield was achieved within \pm 10 per cent variation proving the validity of the equations (Table 1). 
Table 1. Results of the STCR experiment on Rice under SRI.

\begin{tabular}{|c|c|c|c|c|c|c|c|}
\hline \multirow{2}{*}{ Treatments } & \multicolumn{3}{|c|}{ Fertilizer doses $\left(\mathrm{kg} \mathrm{ha}^{-1}\right)$} & \multirow{2}{*}{$\begin{array}{l}\text { Grain Yield } \\
\left(\mathrm{t} \mathrm{ha}^{-1}\right)\end{array}$} & \multirow{2}{*}{$\begin{array}{c}\text { Per cent } \\
\text { achievement }\end{array}$} & \multirow{2}{*}{$\begin{array}{c}\text { Response } \\
\left(\mathrm{kg} \mathrm{ha}^{-1}\right)\end{array}$} & \multirow{2}{*}{$\begin{array}{c}\text { Response Ratio } \\
\left(\mathrm{kg} \mathrm{kg}^{-1}\right)\end{array}$} \\
\hline & $\mathbf{N}$ & $\mathbf{P}_{2} \mathbf{O}_{5}$ & $\mathrm{~K}_{2} \mathrm{O}$ & & & & \\
\hline Blanket & 150 & 50 & 50 & 5.36 & - & 2820 & 11.28 \\
\hline STCR-NPK alone- $7 \mathrm{t} \mathrm{ha}^{-1}$ & 203 & $100 * *$ & $100 * *$ & 7.10 & 101.4 & 4560 & 11.32 \\
\hline STCR-NPK alone- $8 \mathrm{t} \mathrm{ha}^{-1}$ & 252 & $100 * *$ & $100 * *$ & 7.92 & 99.0 & 5380 & 11.90 \\
\hline STCR-NPK alone- $9 \mathrm{t} \mathrm{ha}^{-1}$ & 300 & $100 * *$ & $100 * *$ & 8.41 & 93.5 & 5875 & 11.75 \\
\hline STCR -IPNS*- $7 \mathrm{t} \mathrm{ha}^{-1}$ & 148 & $87 * *$ & $100 * *$ & 7.67 & 109.6 & 5135 & 12.74 \\
\hline STCR -IPNS*- $8 \mathrm{tha}^{-1}$ & 197 & $100 * *$ & $100 * *$ & 8.52 & 106.6 & 5985 & 13.24 \\
\hline STCR -IPNS*- $9 \mathrm{t} \mathrm{ha}^{-1}$ & 246 & $100 * *$ & $100 * *$ & 8.65 & 96.1 & 6110 & 12.22 \\
\hline FYM@12.5 t ha-1 & 0 & 0 & 0 & 3.25 & - & - & - \\
\hline Absolute Control & 0 & 0 & 0 & 2.54 & - & - & - \\
\hline
\end{tabular}

*FYM@12.5 tha ${ }^{-1}$

Table 2. Results of STCR-IPNS validation experimental trial on SRI-Rice.

\begin{tabular}{|c|c|c|c|c|c|c|}
\hline \multirow{2}{*}{ Treatments } & \multicolumn{3}{|c|}{ Fertiliser doses $\mathrm{m}\left(\mathrm{kg} \mathrm{ha}^{-1}\right)$} & \multirow{2}{*}{$\begin{array}{c}\text { Grain yield } \\
\left(t \text { ha }^{-1}\right)\end{array}$} & \multirow{2}{*}{$\begin{array}{c}\text { Percent } \\
\text { achievement }\end{array}$} & \multirow{2}{*}{$\underset{\left(\mathrm{kg} \mathrm{kg}^{-1}\right)}{\mathrm{RR}}$} \\
\hline & FN & $\mathrm{FP}_{2} \mathrm{O}_{5}$ & $\mathrm{FK}_{2} \mathrm{O}$ & & & \\
\hline Blanket & 150 & 50 & 50 & 5.60 & - & 10.96 \\
\hline STCR- NPK alone $-7 \mathrm{t} \mathrm{ha}^{-1}$ & 167 & 40 & $25^{*}$ & 7.06 & 100.9 & 18.10 \\
\hline STCR - NPK alone- $8 \mathrm{tha}^{-1}$ & 201 & 57 & $25^{*}$ & 7.87 & 98.4 & 17.70 \\
\hline STCR - NPK alone - $9 \mathrm{t} \mathrm{ha}^{-1}$ & 236 & 73 & $25 *$ & 8.19 & 91.0 & 15.96 \\
\hline STCR-IPNS - $7 \mathrm{t} \mathrm{ha}^{-1}$ & 125 & 18 & $25^{*}$ & 7.31 & 104.4 & 19.18 \\
\hline STCR-IPNS - $8 \mathrm{t} \mathrm{ha}^{-1}$ & 159 & 35 & $25^{*}$ & 8.28 & 103.5 & 19.15 \\
\hline STCR-IPNS- $9 \mathrm{t} \mathrm{ha}^{-1}$ & 194 & 51 & $25^{*}$ & 8.35 & 92.8 & 16.44 \\
\hline Farmer's practice & 75 & 50 & 50 & 4.50 & - & 9.37 \\
\hline Control & 0 & 0 & 0 & 2.86 & - & - \\
\hline SEd & - & - & - & 0.27 & - & - \\
\hline $\mathrm{CD}(\mathrm{P}=0.05)$ & - & - & - & 0.58 & _- & _- \\
\hline
\end{tabular}

STCR-IPNS: NPK+FYM @ 12.5 tha $^{-1}$; *maintenance dose

Table 3. Pooled analysis of paddy grain yield.

\begin{tabular}{|c|c|c|c|c|c|c|}
\hline \multirow{2}{*}{ Treatments } & \multicolumn{2}{|c|}{ Yield $\left(\mathrm{t} \mathrm{ha}^{-1}\right)$} & \multirow{2}{*}{ Mean } & \multirow{2}{*}{ 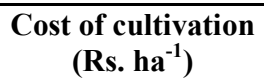 } & \multirow{2}{*}{$\begin{array}{l}\text { Gross Income } \\
\left(\text { Rs. } \text { ha }^{-1}\right)\end{array}$} & \multirow{2}{*}{ B:C } \\
\hline & 2013-14 season & 2014-15 season & & & & \\
\hline $\mathrm{T}_{1}$ & 5.36 & 5.60 & 5.48 & 47983 & 81540 & 1.70 \\
\hline $\mathrm{T}_{2}$ & 7.10 & 7.06 & 7.08 & 43882 & 95844 & 2.18 \\
\hline $\mathrm{T}_{3}$ & 7.92 & 7.87 & 7.90 & 45091 & 106476 & 2.36 \\
\hline $\mathrm{T}_{4}$ & 8.41 & 8.19 & 8.30 & 46265 & 110932 & 2.40 \\
\hline $\mathrm{T}_{5}$ & 7.67 & 7.31 & 7.49 & 45465 & 99492 & 2.19 \\
\hline $\mathrm{T}_{6}$ & 8.52 & 8.28 & 8.40 & 46674 & 112610 & 2.41 \\
\hline $\mathrm{T}_{7}$ & 8.65 & 8.35 & 8.50 & 47848 & 114204 & 2.39 \\
\hline $\mathrm{T}_{8}$ & 3.25 & 4.50 & 3.88 & 45060 & 59530 & 1.32 \\
\hline $\mathrm{T}_{9}$ & 2.54 & 2.86 & 2.70 & 38866 & 42570 & 1.10 \\
\hline SED & 0.29 & 0.27 & 0.28 & - & - & - \\
\hline $\mathrm{CD}(\mathrm{P}=0.05)$ & 0.61 & 0.58 & 0.56 & - & - & - \\
\hline
\end{tabular}

According to Velayutham et al. (1984), if the targeted yield was achieved within \pm 10 per cent variation, then the equations are found to be valid. The grain yield of rice ranged from $2.54 \mathrm{t} \mathrm{ha}^{-1}$ in absolute control to 8.65 $\mathrm{t} \mathrm{ha}^{-1}$ in STCR-IPNS-9 $\mathrm{tha}^{-1}$. Among the treatments, STCR-IPNS-9 $\mathrm{t} \mathrm{ha}^{-1}$ had recorded relatively higher grain yield $\left(8.65 \mathrm{tha}^{-1}\right)$ followed by STCR-IPNS- $8 \mathrm{t}$ ha ${ }^{-1}$ which had also recorded comparable yields (8.52 tha $\left.{ }^{-1}\right)$. However, relatively higher response ratio was recorded in STCR-IPNS-8 $\mathrm{t} \mathrm{ha} \mathrm{ha}^{-1}\left(13.24 \mathrm{~kg} \mathrm{~kg}^{-1}\right)$ followed by STCR-NPK alone $-7 \mathrm{t} \mathrm{ha}^{-1}\left(12.74 \mathrm{~kg} \mathrm{~kg}^{-1}\right)$ as compared to STCR-IPNS-9 $\mathrm{t} \mathrm{ha}^{-1}$ and STCR-NPK alone-9 $\mathrm{t}$ $\mathrm{ha}^{-1}$ treatments. This might be due to the better use efficiency of applied NPK fertilizers at low yield target levels (Santhi et al., 2002). In blanket and farm yard manure@12.5 t ha ${ }^{-1}$, the grain yield was 5.36 and $3.25 \mathrm{tha}^{-1}$ respectively.

In the validation of experimental trial, the grain yield of rice varied from $2.86 \mathrm{t} \mathrm{ha}^{-1}$ in absolute control to $8.35 \mathrm{t} \mathrm{ha}^{-1}$ in STCR-IPNS-9 $\mathrm{t} \mathrm{ha}^{-1}$ (Table 2). Among the treatments, STCR-IPNS-9 $\mathrm{t} \mathrm{ha}^{-1}$ was recorded relatively higher grain yield $\left(8.35 \mathrm{t} \mathrm{ha}^{-1}\right)$ followed by STCR-IPNS-8 $\mathrm{tha}^{-1}$ which had also recorded comparable yields $\left(8.28 \mathrm{tha}^{-1}\right)$. The increase in grain yield owing to STCR approach might be due to balanced application of nutrients which is based on soil analysis and takes into account the amount of nutrient removed by the crops, initial levels of soil fertility, efficiency of nutrients present in thesoil and added through the fertilizers. These factors might have provided the optimum 


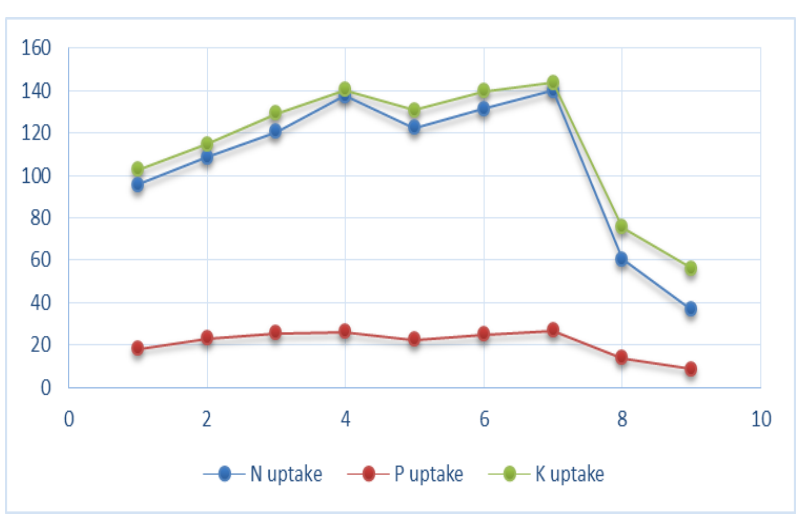

Fig. 1. Effectof STCR-IPNS in nutrient uptake on SRI-Rice.

nutrients at optimum time for better up take and ultimately resulted in higher dry matter and yield, also reported by Satalagaon et al. (2014) in onion crop. However, relatively higher response ratio was recorded in STCR-IPNS-7 t ha- $\left(19.18 \mathrm{~kg} \mathrm{~kg}^{-1}\right)$ followed by STCR-NPK alone- $8 \mathrm{t} \mathrm{ha}^{-1}\left(17.70 \mathrm{~kg} \mathrm{~kg}^{-1}\right)$ as compared to STCR-IPNS-9 $\mathrm{t} \mathrm{ha}^{-1}$ and STCR-NPK alone- $9 \mathrm{t} \mathrm{ha}^{-1}$ treatments. The yield targeting with IPNS recorded relatively higher percent achievement than that aimed under their respective NPK alone treatments. It is evident from the data that lower yield targets were better achieved than the higher one in cotton crops (Praveena Katharine et al., 2013). In blanket and farmer's practice, the rice grain yield was 5.60 and $4.50 \mathrm{t} \mathrm{ha}^{-1}$ respectively; RR was 10.96 and $9.37 \mathrm{~kg} \mathrm{~kg}^{-1}$ respectively proving the superiority of STCR-IPNS.

Response ratio (RR): The response ratio for various treatments ranged between $9.37 \mathrm{~kg} \mathrm{~kg}^{-1}$ and $19.18 \mathrm{~kg}$ $\mathrm{kg}^{-1}$. Among the targets tried, targeting for $7 \mathrm{t} \mathrm{ha}^{-1}$ recorded relatively higher RR than with $9 \mathrm{t} \mathrm{ha}^{-1}$ though it has recorded significantly higher yields. This might be due to the better use efficiency of applied NPK fertilizers at low yield target levels. Likewise, IPNS treatments recorded higher RR when compared to their respective NPK alone treatments. Blanket recorded 10.96 RR which is lower than STCR treatments. The relatively higher RR recorded under STCR and IPNS treatments when compared to blanket, might be due to balanced supply of nutrients from fertilizer, efficient utilization of applied fertilizer nutrients in the presence of organic sources and the synergistic effect of the conjoint addition of various sources of nutrients (SubbaRao and Srivastava, 2000). Similar trend of superiority of STCR-IPNS over farmer"s practice was reported by Coumaravel (2012) for maize-tomato sequence.

Uptake of nutrients and Post-harvest soil fertility status: The maximum nitrogen uptake $\left(140 \mathrm{~kg} \mathrm{ha}^{-1}\right)$, Phosphorous uptake $\left(26.9 \mathrm{~kg} \mathrm{ha}^{-1}\right)$ and potassium uptake $\left(143.8 \mathrm{~kg} \mathrm{ha}^{-1}\right)$ was recorded in $\mathrm{T}_{9}$ where STCR -IPNS-9 $\mathrm{t} \mathrm{ha}^{-1}$. This treatment was statistically on par with $T_{4}, T_{5}$ and $T_{7}$ treatments. The lowest level of N, P and $\mathrm{K}$ nutrient uptake was found in case of $\mathrm{T}_{9}(36.7 \mathrm{~kg}$

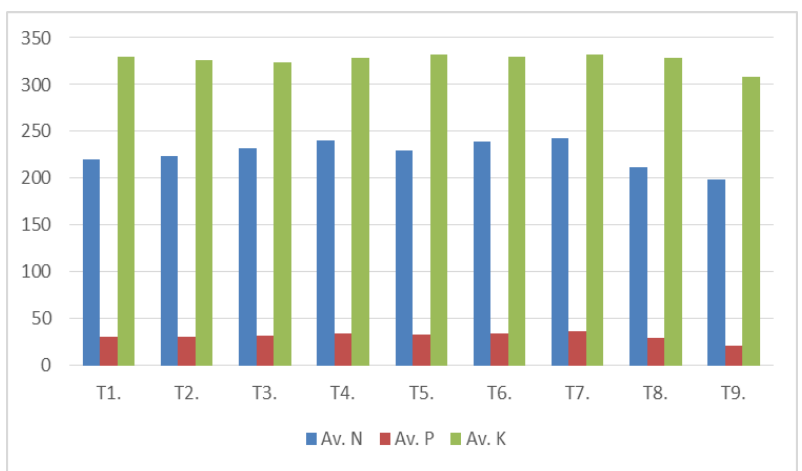

Fig. 2. Effect of STCR-IPNS in available nutrients (post-harvest soil) on SRI-Rice.

$\left.\mathrm{ha}^{-1}\right),\left(8.6 \mathrm{~kg} \mathrm{ha}^{-1}\right)$ and $\left(56.0 \mathrm{~kg} \mathrm{ha}^{-1}\right)$, respectively (Fig. 1).The data on $\mathrm{KMnO}_{4}-\mathrm{N}$, Olsen-P and $\mathrm{NH}_{4} \mathrm{OAc}-\mathrm{K}$ indicated the build up and maintenance of soil fertility due to soil test based fertilizer recommendation under IPNS and there was depletion in absolute control as compared to initial soil available N, P and K. Despite higher removal of nutrients, the fertility status was maintained at higher level in IPNS as compared to NPK alone (Fig. 2). This might be attributed to the prevention of losses of nutrients under IPNS, even after meeting the crop needs. The findings of Pachauri and Vinay Singh (2001) and Santh et al. (2002) supported the results recorded in the present study. In order to find out the reliability of the performance of the different treatments tried, the data on grain yield was pooled over two years of experiment and the results are presented in Table 3. The mean grain yield varied from 2.7 to $8.5 \mathrm{tha}^{-1}$, among the treatments the STCR-IPNS $9 \mathrm{t} \mathrm{ha}^{-1}$ was recorded relatively higher grain yield which was significantly different from other treatments while the lowest was recorded in the treatment of control (2.7 $\left.\mathrm{t} \mathrm{ha}^{-1}\right)$. However, theSTCR-IPNS $8 \mathrm{tha}^{-1}$ recorded the higher B: C ratio of 2.41 followed by STCR $9 \mathrm{t} \mathrm{ha}^{-1}$, while the lower B: C ratio of 1.10 was recorded in control. Therefore, it may be contended that STCR-IPNS 8 $t \mathrm{tha}^{-1}$ was effective and economical.

\section{Conclusion}

To conclude, soil test based IPNS for desired yield targets of rice was developed and validated on Lithic Haplusteptsoils of Tamil Nadu in the present investigation taking into account the nutrient requirement and contribution of $\mathrm{N}, \mathrm{P}$ and $\mathrm{K}$ from various nutrient sources (soil, fertilizer and FYM). The STCR-IPNS @ $8 \mathrm{t} \mathrm{ha}^{-1}$ was effective and economical as compare with any other treatments. The study will help to make guidelines for the amount of fertilizer used in rice cultivation. The specific yield equation based on soil health will not only ensure sustainable crop production but will also steer the farmers towards economic use of costly fertilizer inputs depending on their financial status and prevailing market price of the crop under consideration. The fertilizer prescription equations developed using this model can be applied to Incepti- 
sols of all tropical regions by substituting the soil nutrient status of the particular field.

\section{REFERENCES}

Ahmed, S., Raizuddin, M. and KrishnaReddy, P. V. (2002) Optimizing fertilizerdoses for rice in alluvial soils through chemical fertilizers, farm yard manureand green manure using soil test values. Agroped.12:133-140

Andrainaivo, B. and Jolei, B. (2002). Assessment of SRI. Proc. International Conference, Sanya, China, April 1-4, Pp. 162

Bera, R., Seal, A., Bhattacharyya, P., Das, T. H., Sarkar, D., Kangjoo, K. (2006) Targeted yield concept and a framework of fertilizer recommendation in irrigated rice domains of subtropical India, J Zhejiang Univ Sci., 7(12): 963-968.

Bhandari, A. L.,Ladha, J. K., Pathak, H, Padre, A. T., Dawae, D., Gupta, R. K. (2002) Yield and soil nutrient changes in a long-term rice-wheat rotation in India, Soil Sci. Soc. Am. 58: 185-193

Coumaravel, K. (2012) Soil test crop response correlation studies through integrated plant nutrition system for maize - tomato sequence, Doctoral diss, Tamil Nadu Agricultural University, Coimbatore.

DAC [Department of Agriculture and Cooperation](2013). Ministry of Agriculture (www.krishijagran.com)

Dobermann, A., Witt, C., Abdulrachman, S., Gines, H. S., Nagarajan, R., Son, T. T., Tan, P. S., Wang, G. H., Chien, N. V., Thoa, V. T. K., Phung, C. V., Stalin, P., Muthukrishnan, P., Ravi, V., Babu, M., Simbahan, G. C. and Adviento, M. A. (2003). Soil fertility and indigenous nutrient supply in irrigated rice domains of Asia. Agronomy J. 95: 913-923

Hanway, J. J. and Heidal, H. (1952). Soil analysis methods as used in Iowa state college soil testing laboratory. Lowa State College of Agriculture Bulletin. 57: 1-31

Jackson, M. L. 1973. Soil Chemical Analysis. Prentice Hall of India Private Limited, New Delhi.

Kadu, P. P. and Bulbule, A. V. (2007). Nutrient requirement of finger millet based on soil test crop response correlation approach. An Asian J. Soil Sci. 2(2): 51-53

Khosa, M. K., Sekhon, B. S., Ravi, M. S., Benipal, D. S., Benbi, D. K. (2012). Performance of target yield based fertilizer prescription equations in rice-wheat cropping system in Punjab, Indian J. Fert. 8(2): 14-18

Ladha, J. K., Dawe, D., Pathak, H., Padre, A. T., Yadav, R. L., Singh, B., Singh, Y., Singh, P., Kundu, A. L., Sakal, R., Ram, N., Regni, A. P., Gami, S. K., Bhandari, A. L., Amin, R., Yadav, C. R., Bhattarai, E. M., Das, S., Aggarwal, H.P., Gupta, R.K. and Hobbs, P.R. (2003). How extensive are yield declines in long-term rice-wheat experiments in Asia? Field Crops Res., 81: 159-180

Liebig Von, J. and Maruthi Sankar, G. R. (1855). Application of statistical model building and optimization techniques in fertilizer use research, Somani, L. L. Vittal, K. P. R. and Venkateswarlu, B. (Ed.), Dry land Agriculture - State of Art of Research in India (Scientific Publishers, Jodhpur, (1992), 653-670

Manna, M. C., Swarup, A., Wanjari, R. H., Ravankar, H. N., Mishra, B., Saha, M. N., Singh, Y. V., Sahi, D. K. and Sarap, P. A. (2005). Long-term effect of fertilizer and manure application on soil organic carbon storage, soil quality and yield sustainability under sub-humid and semi-arid tropical India, Field Crops Res., 93: 264-280

Olsen, S. R., Cole, C. V., Watanabe, F. S. and Dean, L. (1954). Estimation of available phosphorus in soils by extraction with sodium bicarbonate. U.S.D.A. Circle. 939. (U.S. Govt. Printing Office: Washington, DC)

Pachauri, S. P. and Vinay Singh. (2001). Effect of integrated use of FYM and chemical fertilizers on fertility of onion soil. Ann .plant and soil res .3: 304-306.

Prasad, S. C. (2006). System of Rice Intensification in India: Innovation History and Institutional Challenges. WWFICRISAT Dialogue on Water, Food and Environment, Patancheru, Hyderabad (http://www.wassan.org/sri/ documents/Shambu_SRI.pdf)

Praveena Katharine, S., Santhi, R., Maragatham, S., Natesan, R., Ravikumar, V. and Pradip Dey. (2013). Soil test based fertilizer prescriptions through inductive cum targeted yield model for transgenic cotton on Inceptisol. IOSR J. Agric. and Veterin. Scie., 6(5): 36-44

Ramamoorthy, B., Narasimham, R. L. and Dinesh, R. S. (1967). Fertilizer application for specific yield targets on Sonora 64 (wheat). Indian Farmi., 17: 43-45

Ravindra Babu, V., Mahendra Kumar, R., Subba Rao, L. V., Surekha K., Padmavathi, Ch., Latha., Prasad, M. S., Vinod, G., Rupela O. P. and Viraktamath B. C. (2006). Evaluation of quality parameters under SRI and conventional method of cultivation. Abstracts of National Symposium on present and future prospect of SRI cultivation" held in ANGRAU - Rajendranagar from 17 $18^{\text {th }}$ November 2006. P. 108

Ray, P. K., Jana, A. K., Maitra, D. N., Saha, M. N.,Chaudhury, J., Saha, S. and Saha, A. R. (2000). Fertilizer prescriptions on soil test basis for jute, riceand wheat in a typic ustochrept. J. Indian Soc. of Soil Sci ., 48: 79-84

Santhi, R., Natesan, R. and Selvakumari, G. (2002). Soil test based fertilizer recommendation under IPNS for aggregatum onion in Inceptisols of Tamil Nadu. Agropedol., 12: $141-147$

Satalagaon, G. S., Chandranath, H. T. and Potdar, M. P. (2014). Response of drill sown onion to nutrient management through soil test crop response (STCR)and soil test laboratory (STL) approach. Karnataka J. Agrl. Sci., 27 (2): 232-233

Season and Crop Report of Tamil Nadu. (2015). Department of Economics and Statistics, Chennai-6

Stockdale, E. A., Lamkin, N. H., Hovi, M., Keatinge, R., Lennartsson, E. K. M., Macdonald, D. W., Padel, S., Tattersall, F. H., Wolfe, M. S. and Watson, C. A. (2001). Agronomic and environmental implications of organic farming systems. Advan. Agron., 70: 261-327

Subba Rao, A. and Srivastava, S. (2000). Soil test based fertilizer use - Amust for sustainable agriculture. Ferti. News, 45: 25-38

Subbiah, B. V. and Asija, G. L. (1956). A rapid procedure for estimation of available nitrogen in soils. Current Sci . 25:259-260

Truog, E., Fifty years of soil testing, Proc. Trans 7th Intl. Congr. Soil Sci. Vol. III Commission IV paper No.7:1960, 46-53.

Velayutham, M., Maruthi Sankar, G.R. and Reddy, K.C.K. (1984). in Annual Report of the All India Co-ordinated Research Project on Soil Test Crop Response correlation (ICAR), (Hyderabad, India): 621-642 